\title{
Lack of EGF receptor contributes to drug sensitivity of human germline cells
}

\author{
S-J Park' ${ }^{1,2}$, S Armstrong', C-H Kim', M Yu ${ }^{3}, K_{\text {Robertson }}^{4}$, MR Kelley',4 and S-H Lee ${ }^{*, 1,2}$ \\ 'Department of Biochemistry and Molecular Biology, Indiana University School of Medicine, Indianapolis, IN 46202, USA; ${ }^{2}$ Walther Oncology Center, \\ Indiana University School of Medicine, Indianapolis, IN 46202, USA; ${ }^{3}$ Department of Medicine-Biostatistics, Indiana University School of Medicine, \\ Indianapolis, IN 46202, USA; ${ }^{4}$ Department of Pediatrics, Indiana University School of Medicine, Indianapolis, IN 46202, USA
}

\begin{abstract}
Germline mutations have been associated with generation of various types of tumour. In this study, we investigated genetic alteration of germline tumours that affect the drug sensitivity of cells. Although all germline tumour cells we tested were hypersensitive to DNA-damaging drugs, no significant alteration was observed in their DNA repair activity or the expression of DNA repair proteins. In contrast, germline tumours expressed very low level of epidermal growth factor receptor (EGFR) compared to drug-resistant ovarian cancer cells. An immunohistochemical analysis indicated that most of the primary germline tumours we tested expressed very low level of EGFR. In accordance with this, overexpression of EGFR in germline tumour cells showed an increase in drug resistance, suggesting that a lack of EGFR, at least in part, contributes to the drug sensitivity of germline tumours.

British Journal of Cancer (2005) 92, 334-34I. doi: I0.1038/sj.bjc.66023I5 www.bjcancer.com

Published online II January 2005

(c) 2005 Cancer Research UK
\end{abstract}

Keywords: DNA damage; epidermal growth factor receptor; drug resistance; cisplatin; cancer; chemotherapy

Germline mutations are associated with generation of various tumours. Previous studies indicated that germline cells were hypersensitive to DNA-damaging agents (Cagnoli et al, 1998). Although the mechanisms, of drug resistance are still poorly understood, an increased rate of DNA adduct removal appears to be associated with drug resistance in various human cancers (Lai et al, 1988; Dinapoli et al, 1993; Johnson et al, 1994; Eastman and Schulte, 1998). Drug-resistant human tumours have been shown to express higher levels of nucleotide excision repair (NER) proteins such as XPA, XPB (Lai et al, 1988; Eastman and Schulte, 1998), ERCC1, and cockayne syndrome group B (CSB) (Lai et al, 1988). Also, altered expression of genes involved in O-6-alkyltransferasemediated direct DNA repair (O-6-methylguanine DNA methyl transferase, MGMT) or base excision repair pathway also contributes to drug resistance of cancer cells (Chetsanga and Lindahl, 1979; Doetsch and Cunningham, 1990; Cohen et al, 1991; Demple and Harrison, 1994; Gill et al, 1996; Deutsch et al, 1997; Asagoshi et al, 2000; Bielas and Heddle, 2000; Dobson et al, 2000; Evans et al, 2000). Defects in mismatch repair (MMR) are associated with cisplatin resistance by contributing to increased replication bypass of cisplatin adducts and to a drug-tolerant phenotype (Hansen et al, 1998; Karahalil et al, 1998; Hansen and Kelley, 2000; Limp-Foster and Kelley, 2000; O’Neill, 2000). Therefore, loss of MMR proteins such as hMLH1 leads to resistance of tumour cells to a variety of DNA-damaging agents, including bifunctional alkylating and monofunctional methylating agents

*Correspondence: Dr S-H Lee, Indiana University Cancer Research Institute, 1044 W Walnut Street, Room 153, Indianapolis, IN 46202, USA; E-mail: slee@iupui.edu

Received 2 August 2004; revised 27 October 2004; accepted 8 November 2004; published online II January 2005
(Rosenquist et al, 1997; Waters et al, 1999; Zharkov et al, 2000) such as cisplatin and $N^{\prime}$-methyl- $N$-nitrosourea (Koi et al, 1994; Fishel and Kolodner, 1995; Fink et al, 1996, 1998; Drummond et al, 1996).

In addition to genetic alteration of DNA repair genes, altered drug transport, increased metallothionein or glutathione levels, mitochondrial alterations, and altered DNA adduct formation have been reported to contribute to drug resistance of human cancers (Graves et al, 1992; Mello et al, 1996; Kuga et al, 1997; Leighton et al, 1997; Mitra et al, 1997; Umar et al, 1997). Growth factor receptor such as epidermal growth factor receptor (EGFR) is also amplified in many solid tumours (Arteaga, 2003). Introduction of a protein tyrosine kinase inhibitor selectively blocks proliferation of EGFR-expressing tumour cells, suggesting a role for EGFR in tumour cell growth (Lydon et al, 1998). Epidermal growth factor receptor is necessary for cisplatin-mediated apoptosis in tumour cells, suggesting a possible involvement of EGFR pathway in mediating the repair of drug-induced DNA damage(s) (Dixit et al, 1997). On the other hand, overexpression of EGFR family members suppressed the antiproliferative/cytotoxic activity of tumour necrosis factor (TNF)-alpha, suggesting that it may have an antagonistic role in TNF pathway (Perez and Donato, 1996; Hoffmann et al., 1998). Nonetheless, overexpression of EGFR observed in human breast/ovarian tumours is associated with poor prognosis with cancer patients (Baekelandt et al, 1999; Witters et al, 1999).

In this study, we investigated the genetic alteration of germline tumours such as altered DNA repair activity and/or damage signalling pathways that affect the drug sensitivity of cells. We found no significant change in NER activity or expression of DNA repair proteins in drug-sensitive germline cells compared to the drug-resistant ovarian cancer cells. Instead, the expression of a membrane receptor tyrosine kinase, EGFR, correlated with the 
cells drug resistance. Drug-resistant cancer cells exhibited elevated level of EGFR expression, while drug-sensitive germline cells showed a lower EGFR expression. Overexpression of the EGFR gene significantly enhanced the cells drug resistance, suggesting that EGFR may be one of the contributing factors that affect drug resistance of cancer cells.

\section{MATERIALS AND METHODS}

Cell lines, cell culture, and drug treatment: NT2/D1 cells were obtained from American Type Culture Collection (Rockville, MD, USA) and $833 \mathrm{~K}$ and $64 \mathrm{CP} 9$ GCT cell lines were obtained from G Sledge (Indiana University School of Medicine, Indianapolis, IN, USA). PA-1 cells were derived from a human teratocarcinoma, human ovarian cancer cells (Hey) were from a peritoneal deposit of a cytoadenocarcinoma of the ovary (from G Mills, MD Anderson Cancer Center, Houston, TX, USA), and a normal ovarian epithelial cell (IOSE80) was obtained from JA Hurteau (Department of Obstetrics and Gynecology, University of Illinois at Chicago, Chicago, IL, USA). All germline and ovarian cells were maintained in MEM supplemented with $10 \%$ fetal bovine serum at $37^{\circ} \mathrm{C}$ in a $\mathrm{CO}_{2}$ incubator, while IOSE 80 was maintained in MEM and 199/MCDB $105(1: 1)$ supplemented with $10 \%$ fetal bovine serum and EGF $\left(10 \mathrm{ng} \mathrm{ml}^{-1}\right)$.

Germ cell tumours (GCTs): Tissue sections of biopsy materials with disseminated GCTs were obtained from the Indiana University Medical Center, University Hospital, under an Indiana University Institutional Review Board approved protocol (IU Study No. 9908-47) as 4\% buffered formaldehyde-fixed tissues embedded in paraffin blocks, which were sectioned at $3 \mathrm{~mm}$ and fixed onto slides. Diagnosis was made from morphological examination of H\&E-stained sections of biopsy material.

Proteins, plasmids, chemicals, and antibodies: Glutathione-Stransferase (GST) fusion form of c-Jun protein containing residues 1-79 of human c-Jun was overexpressed from Escherichia coli and purified using glutathione-agarose affinity column chromatography as described previously (Park et al, 2001). $\left[\gamma-{ }^{32} \mathrm{P}\right]$ ATP $\left(4500 \mathrm{Ci} \mathrm{mmol}^{-1}\right)$ was obtained from ICN. Adriamycin, EGF mitomycin C (MMC), and cisplatin were purchased from Sigma Chemical Co. (St Louis, MO, USA). Antibodies to EGFR, proliferating cell nuclear antigen (PCNA), c-Abl, Ku70/80, the catalytic subunit of DNA-dependent protein kinase (DNA-PKcs), JNK1 and/or JNK1/2 were obtained from either Santa Cruz Biotechnology (Santa Cruz, CA, USA) or Pharmingen (San Diego, CA, USA).

Cell survival assay: To examine drug resistance of cells, cells $\left(1.0 \times 10^{4}\right.$ cells well $\left.{ }^{-1}\right)$ were plated in a 96 -well plate and incubated for $24 \mathrm{~h}$. Cells were treated with drugs and further incubated at $37^{\circ} \mathrm{C}$ and $5 \% \mathrm{CO}_{2}$ for $72 \mathrm{~h}$. After $72 \mathrm{~h}$ incubation, cell survival was measured using a colorimetric cell survival assay from Boehringer Mannheim (MTT Cell Proliferation Kit). Alternatively, clonogenic assay was used to measure the ability of cells to form colonies on $100 \mathrm{~mm}^{2}$ tissue culture dishes following treatment with ionising radiation or cisplatin. Controls consisted of cells untreated with peptides or DNA-damaging agent, or with neither. Cells were continuously exposed for 5 days to the indicated concentrations of the peptide, and colonies were stained with crystal violet and then colonies greater than 50 cells were counted. Each point represents mean values \pm s.e., each conducted with triplicate plates.

Immunohistochemistry: Tissue sections were visualised for EGFR expression using an anti-EGFR monoclonal antibody (Santa Cruz Biotech., Santa Cruz, CA, USA). The Dako Universal Staining system (Dako Corp., Carpinteria, CA, USA) was used to automate the immunostaining procedure (Robertson et al, 2001). Sections were treated with $3 \% \mathrm{H}_{2} \mathrm{O}_{2}$ for $10 \mathrm{~min}$ and incubated with an antiEGFR antibody $(1: 1000)$ for $25 \mathrm{~min}$, the biotinylatd goat antimouse antibody IgG secondary antibody for $10 \mathrm{~min}$, streptavidin - horseradish peroxidase for $10 \mathrm{~min}$, and diaminobenzidine for $5 \mathrm{~min}$, according to Dako recommendation and empiric determination.

JNK immunocomplex assay: For JNK assay, cells were grown in culture media containing $0.5 \%$ fetal bovine serum for $16 \mathrm{~h}$ prior to the treatment with EGF or genotoxic agents. Cells were washed in ice-cold phosphate-buffered saline (PBS) and $0.5 \mathrm{ml}$ of JNK lysis buffer (25 mM HEPES, pH 7.5, $0.3 \mathrm{M} \mathrm{NaCl}, 1.5 \mathrm{mM} \mathrm{MgCl}_{2}, 0.2 \mathrm{~mm}$ EDTA, $0.5 \mathrm{~mm}$ dithiothreitol (DTT), 0.5\% Triton X-100, $20 \mathrm{~mm} \beta$ glycerophosphate, $1 \mathrm{~mm}$ sodium vanadate, $0.1 \mu \mathrm{m}$ okadaic acid, $1 \mathrm{~mm}$ phenylmethylsulphonyl fluoride, $20 \mu \mathrm{g} \mathrm{ml}^{-1}$ aprotinin, $50 \mu \mathrm{g} /$ $\mathrm{ml}^{-1}$ leupeptin, and $10 \mu \mathrm{M}$ pepstatin) added to the dishes $(150 \times 25 \mathrm{~mm})$ before scraping. After $30 \mathrm{~min}$ incubation on ice, insoluble materials were removed by centrifugation for $30 \mathrm{~min}$ at 12000 r.p.m. JNK activity was determined by an immunocomplex assay essentially as described (Litz-Jackson et al, 1992; Duyster et al, 1995). Briefly, cell extracts $(200 \mu \mathrm{g})$ were mixed with $1.5 \mu \mathrm{l}$ of anti-JNK1/JNK2 polyclonal antibody for $1 \mathrm{~h}$, and then $15 \mu \mathrm{l}$ of protein $\mathrm{A}$-Sepharose beads was added and further incubated for $3 \mathrm{~h}$ at $4{ }^{\circ} \mathrm{C}$. The immunocomplex was washed three times with JNK lysis buffer and once with JNK kinase reaction buffer $(20 \mathrm{mM}$ HEPES pH 7.5, $10 \mathrm{~mm} \mathrm{MgCl}_{2}, 7 \mathrm{~mm} \mathrm{MnCl}_{2}, 1 \mathrm{~mm}$ EGTA, $1 \mathrm{~mm}$ sodium fluoride, $1 \mathrm{~mm}$ sodium vanadate, and $1 \mathrm{~mm}$ DTT). The precipitate was then resuspended in $30 \mu \mathrm{l}$ of JNK reaction buffer containing $2 \mu \mathrm{g}$ of GST-c-Jun (Park et al, 2001) and $50 \mu \mathrm{M}$ ATP and the reaction was initiated by the addition of $1.0 \mu$ l of $\left[\gamma_{-}{ }^{32} \mathrm{P}\right] \mathrm{ATP}$ $\left(45000 \mathrm{Ci} \mathrm{mmol}^{-1}\right)$. After incubation for $20 \mathrm{~min}$ at $30^{\circ} \mathrm{C}$, the reaction was terminated by the addition of $8 \mu \mathrm{l}$ of $4 \times$ SDS sample buffer (Laemmli, 1970) and heating to $95^{\circ} \mathrm{C}$ for $5 \mathrm{~min}$. Samples were analysed on a $12 \%$ SDS-PAGE.

Western blot analysis: Extracts $(40 \mu \mathrm{g})$ from various ovarian cancer cells were loaded onto a 6 or 10\% SDS-PAGE, and following gel electrophoresis proteins were transferred to nitrocellulose membrane and immunoblotted with primary antibody followed by a peroxidase-coupled secondary antibody (Amersham) and an enhanced chemiluminescence (Amersham) reaction prior to visualisation on a Kodak-o-mat film.

Transfection and selection of stable cell lines: Cells were transfected with either pEGFR-GFP or pEGFP-N3 using Lipofect AMIINE method (Life Technologies Inc.). Following antibiotic selection with G418 $\left(600 \mu \mathrm{g} \mathrm{ml}^{-1}\right.$, Geneticin-Life Technologies, Gaithersburg, MD, USA), several EGFR-expressing clones were isolated and expanded into cell lines. Individual clonal lines expressing EGFR-GFP were established by plating a single cell into 96-well dishes. Cell clones expressing EGFR-GFP were utilised for the drug resistance study.

Immunofluorescence microscopy: PA-1 cells were grown on cover slides, washed twice with PBS, fixed in $-10^{\circ} \mathrm{C}$ methanol for $5 \mathrm{~min}$, air dried, and washed three times again with PBS. Fixed cells were incubated with an anti-EGFR polyclonal antibody (Santa Cruz Biotech.; $2 \mu \mathrm{g} \mathrm{ml}^{-1}$ ) at room temperature for $1 \mathrm{~h}$. After washing with PBS three times, cells were incubated for $1 \mathrm{~h}$ in the dark at room temperature with a 1:10 dilution of the secondary antibody (fluorescein-conjugated goat anti-mouse antibody; Oncogene Science) in PBS with $3 \%\left(\mathrm{wv}^{-1}\right)$ milk. Following extensive washing with PBS (five times), slides were prepared using $90 \%$ glycerol in $\mathrm{PBS}$ and stored in the dark at $4{ }^{\circ} \mathrm{C}$. Images were collected using a CCD 4910 camera with NIH image on a Zeiss Axiophot microscope.

In vitro NER activity: Reaction mixtures $(50 \mu \mathrm{l})$ contained $0.2 \mu \mathrm{g}$ each of UV-irradiated $\left(450 \mathrm{~J} \mathrm{~m}^{-2}\right) \mathrm{pBS}(3 \mathrm{~kb})$ and nonirradiated pBS $(4.5 \mathrm{~kb}), 40 \mathrm{~mm}$ creatine phosphate-di-Tris salt ( $\mathrm{pH} 7.7), 1 \mu \mathrm{g}$ creatine kinase, $50 \mathrm{~mm}$ HEPES-KOH ( $\mathrm{pH} \mathrm{7.8),} 70 \mathrm{~mm} \mathrm{KCl,} 7.5 \mathrm{~mm}$ $\mathrm{MgCl}_{2}, 0.5 \mathrm{~mm}$ DTT, $0.4 \mathrm{~mm}$ EDTA, $2 \mathrm{~mm}$ ATP, $20 \mu \mathrm{M}$ of dGTP, dCTP, dTTP, $8 \mu \mathrm{M}$ of $\left[\alpha^{-}{ }^{32} \mathrm{P}\right.$ dATP $\left(25000 \mathrm{cpm} \mathrm{pmol}^{-1}\right), 5 \mu \mathrm{g}$ of $\mathrm{BSA}$, and increasing amount of cell extracts (150 and $300 \mu \mathrm{g})$ from various cells (Stigger et al, 1998). After incubation for $3 \mathrm{~h}$ at $30^{\circ} \mathrm{C}$, DNA was isolated from the reaction mixtures, linearized with 
$B a m \mathrm{H} 1$, and separated on a $1 \%$ agarose gel electrophoresis in the presence of $0.5 \mu \mathrm{g} \mathrm{ml}^{-1}$ ethidium bromide. Repair products were analysed by both fluorography and exposure to X-ray film.

\section{RESULTS}

\section{Germline cells exhibit hypersensitivity to DNA-damaging drugs}

To analyse drug resistance of germline cells, four established germline tumour cells (PA-1, NT2/D1, 833K, and 64CP9) were compared with a normal ovarian epithelial cell line (IOSE80) and drug-resistant ovarian cancer cells (Hey) derived from a peritoneal deposit of a cytoadenocarcinoma of the ovary (Figure 1). The established ovarian cancer cells (Hey) showed a marked resistance to cisplatin treatment, while the germline tumour cells were remarkably sensitive to the drug treatment (Figure 1). All four germline tumour cells showed extreme sensitivity to cisplatin treatment $(5 \mu \mathrm{M})$ with a survival rate of less than $10 \%$, whereas $80 \%$ of Hey cells survived under the same conditions. Meanwhile, a primary epithelial ovarian cell (IOSE80) showed a medium level of cell survival following cisplatin treatment (Figure 1). Adriamycin is a DNA-intercalating agent that causes DNA strand break damage, while MMC mainly causes DNA damage by forming a DNA crosslink. Similar to the cisplatin treatment, germline tumour cells were highly sensitive to both MMC and adriamycin treatment (Figure $1 \mathrm{~B}$ and $\mathrm{C}$ ).

\section{Drug sensitivity of germline cells correlates with the lack of EGFR expression}

To better understand the hypersensitivity of germline tumour cells to DNA-damaging drug, we analysed expression of various proteins that are involved in the drug sensitivity of cells. No noticeable difference was observed between drug-sensitive germline tumour cells and a drug-resistant cell (Hey) in the expression of DNA repair proteins (PCNA, TFIIH, DNA-PKcs, and Ku70/80) (Figure 2). We noticed however some difference in the expression of DNA-PKcs (Figure 2), although this subtle difference was not consistently observed in multiple experiments (data not shown).
Also, we did not see any significant difference between germline cells and Hey cells in the in vitro NER activity (data not shown). Interestingly, a significant difference was observed in the expression of EGFR between germline tumour cells and ovarian cancer (Hey) cells, while the expression of JNK1 and JNK2 showed no difference between them (Figure 2).

\section{Expression of EGFR enhances the drug resistance of germline cells}

To further examine whether the lack (or low level) of EGFR expression in germline tumour cells (Figure 3A) contributes to their drug sensitivity, cells were transfected with plasmid DNA expressing either green fluorescence protein (GFP) or GFP-EGFR fusion protein and analysed for their effect on drug resistance of cells. After initial selection of cells expressing GFP or GFP-EGFR, protein expression and cellular localization were analysed by Western blot (Figure 3B) and by fluorescence microscopy (Figure 3C), respectively. Germline tumour cells harbouring pEGFR-GFP plasmid showed a high level of EGFR expression, which was comparable to that in drug-resistant ovarian cancer (Hey) cells (Figure 3B). Cells harbouring pEGFR-GFP not pEGFPN3 showed EGF-dependent activation of JNK1, suggesting that GFP-EGFR fusion protein is functionally active (data not shown).

Germline cells transfected with pEGFR-GFP showed only a marginal increase in their cell survival following cisplatin treatment, while cells expressing GFP (pEGFP-N3) exhibited a slight decline in cell survival (Figure 4 and Table 1). When a stably transfected cell instead of transient system was examined for drug sensitivity, however, it not only showed a significant increase in EGFR expression, but also enhanced survival of germline tumour cells following cisplatin treatment (Figure 5 and Table 1). Although EGFR kinase is activated by EGF, we did not see a substantial increase in cell survival in the presence of EGF probably because EGFR can also be activated by cisplatin. The difference in cell survival between transiently transfected cells (Figure 4) vs stable transfectants (Figure 5) following drug treatment may be due to the lower transfection efficiency in transient system, where only $30 \%$ of cells expressed GFP-EGFR (data not shown). Together, our results suggest that (1) a lack (or lower level) of EGFR expression
A

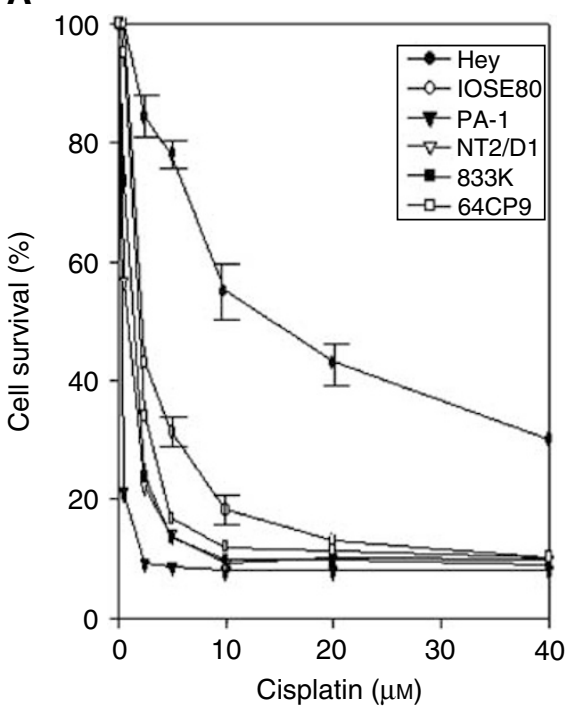

B

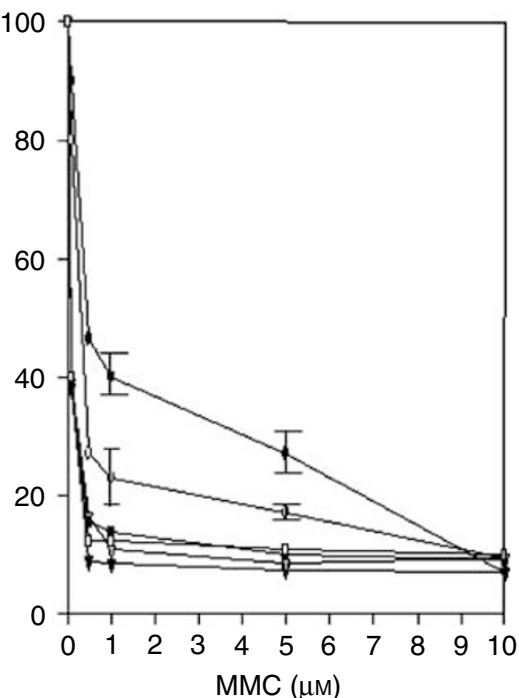

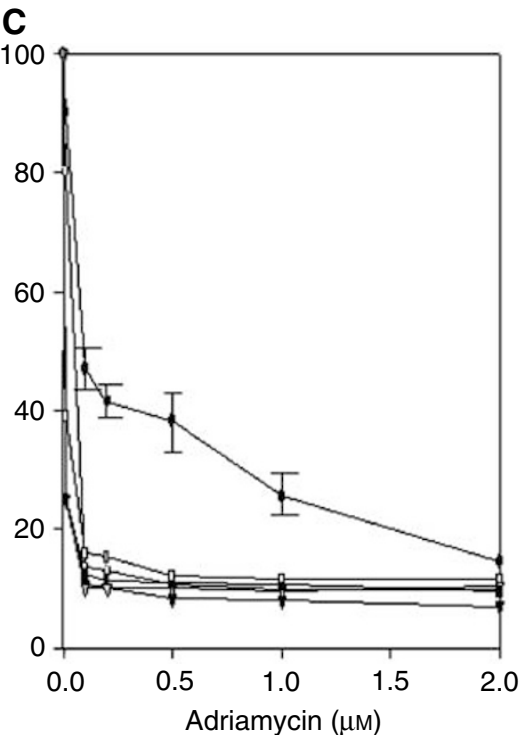

Figure I Effect of various drugs on the survival of GCTs (PA-I, 833K, NT2/DI, and 64CP9), ovarian primary epithelial cells (IOSE 80), and ovarian cancer cells (Hey). Cells were treated for $72 \mathrm{~h}$ with various concentrations of cisplatin $(\mathbf{A}), M M C(\mathbf{B})$, and adriamycin $(\mathbf{C})$. Percentage of surviving cells was monitored using MTT assay and the results are the averages of three independent assays. 
in germline tumour cells contributes to their drug sensitivity and (2) EGFR may play a positive role in protecting cells following treatment of cells with DNA-damaging agent.

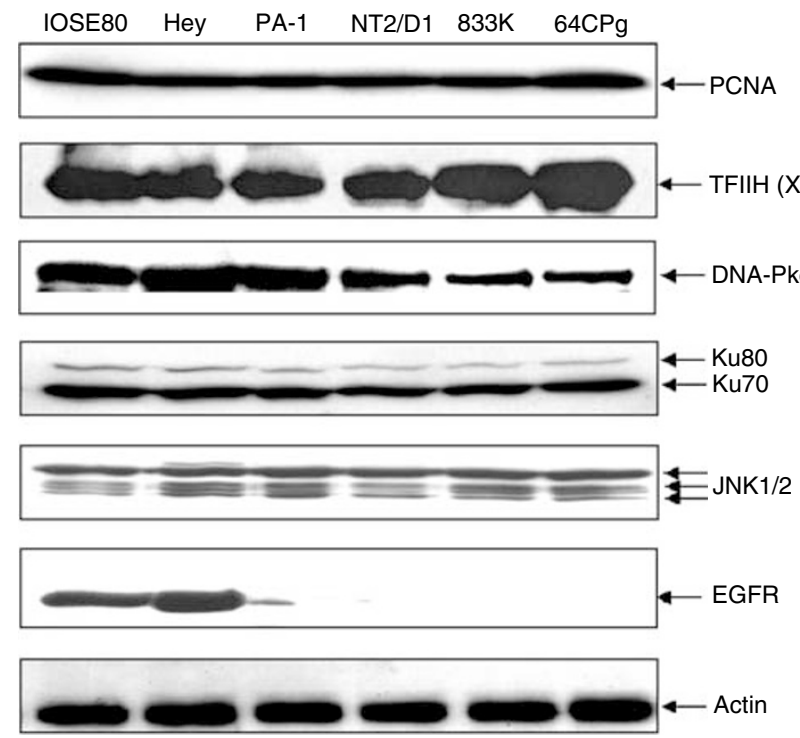

Figure 2 Expression of various proteins in germline cells. Extracts $(100 \mu \mathrm{g})$ from various germline tumour cells (PA-I, 833K.NT2/DI, and 64CP9) and ovarian cells (Hey and IOSE-80) were analysed for the expression of DNA repair factors or damage signalling proteins by Western blot.

A

\begin{tabular}{|lllll} 
Hey & PA-1 & 833K & NT2/D1 64CPg \\
\hline & & & \\
\hline & & & \\
\hline
\end{tabular}

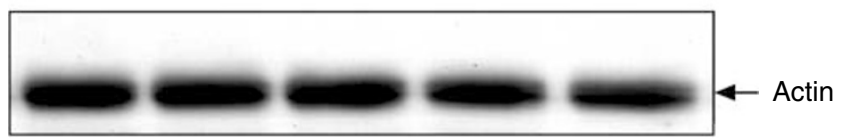

c

Lack (or lower level) of EGFR expression in primary germline cells

To see whether lack or lower level of EGFR expression is a common property of germline tumour cells, a number of primary GCTs were selected and tested for EGFR expression. Among 61 GCTs tested, 35 showed undetectable level of EGFR expression, while the remaining samples expressed very low level of EGFR compared to a control ovarian cancer cells (Table 2), supporting the observation with established cells (PA-1, NT2/D1, 833K, and 64CP9) that germline tumours express lower level of EGFR (Figure 3). In fact, the probability of all 61 GCT samples having EGFR expression no higher than + is extremely low $\left(2 \times 10^{-25}\right)$.

\section{DISCUSSION}

Alteration of DNA repair factors or damage response proteins has been associated with drug resistance of cancer cells (Mohrenweiser et al, 2003). For example, a tumour suppressor gene, p53, is a key DNA damage mediator that plays a dual role following exposure to cytotoxic treatment (Ferrera et al, 1999); it is involved in damageinduced apoptosis, but also plays a role in cell cycle arrest and DNA repair, cellular processes that can affect the sensitivity to chemotherapeutic drug. However, a consensus on the role for DNA repair genes in drug resistance of various cancer cells has not been reached, mainly because the complicated nature of drug-induced resistance with various tumours made it difficult to delineate a single mechanism (such as DNA repair) that contributes to the resistance.

Compared to drug-resistant ovarian cancer cells, germline tumour cells showed a marked sensitivity following the treatment

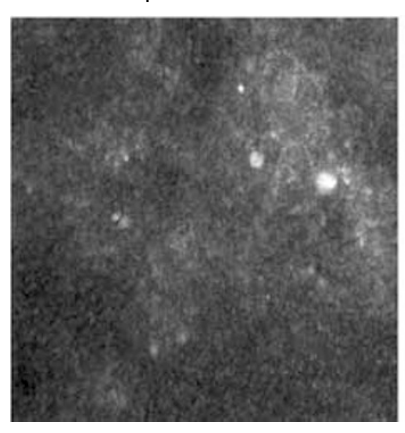

\section{B Hey}

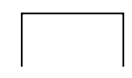

$-$

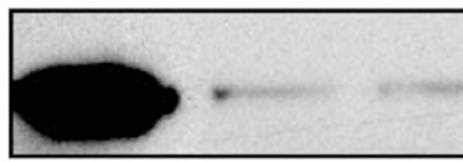


A $833 \mathrm{~K}$ cells

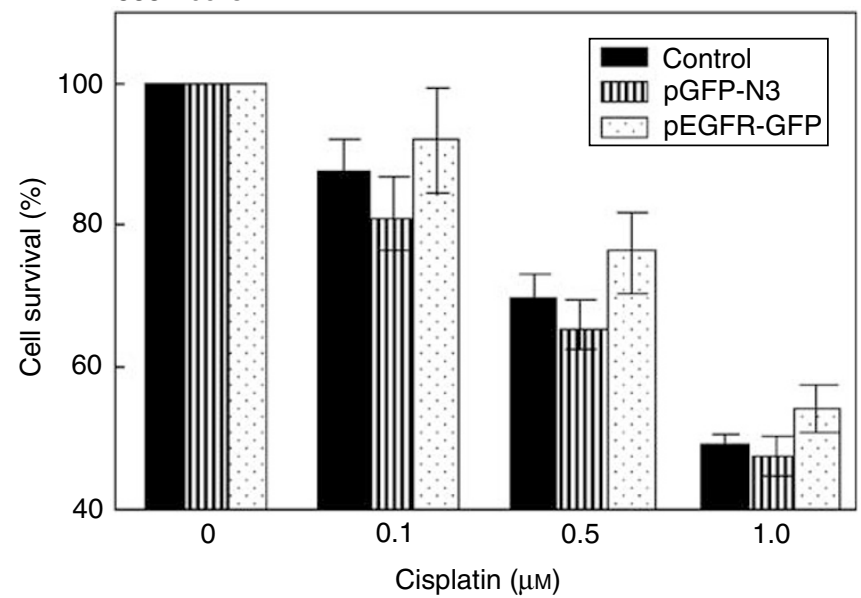

B $\quad 64 \mathrm{CP} 9$ cells

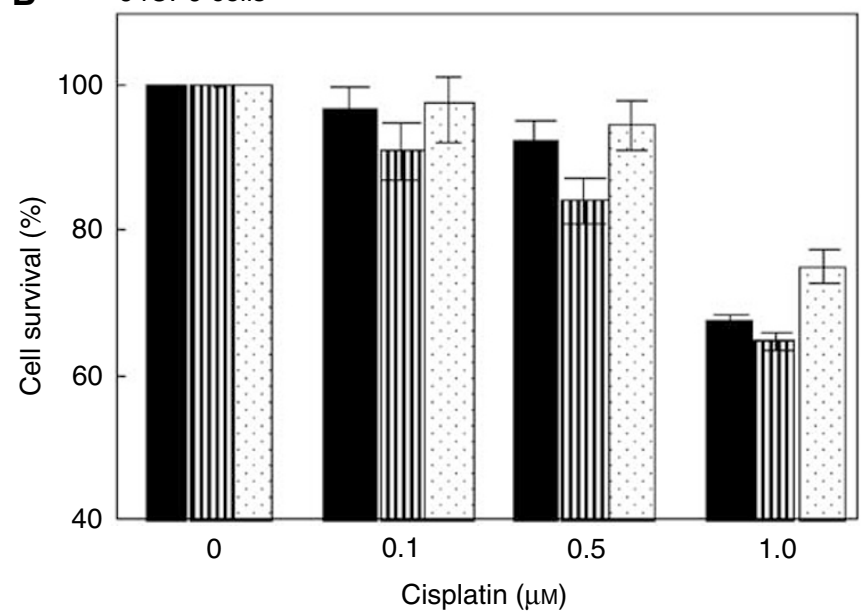

Figure 4 Transient expression of EGFR enhances the survival of two germline tumour cells (833K (A); 64CP9 (B)) following cisplatin treatment Control cells were compared with those transiently transfected with either pEGFP-N3 vector or pEGFR-GFP and examined for their cell survival following cisplatin treatment. At $24 \mathrm{~h}$ after transfection, cells were exposed to the indicated amount of cisplatin for $72 \mathrm{~h}$. The percentage of surviving cells was monitored by MTT assay.

Table I Effect of EGFR expression on cisplatin resistance of germline tumour cells $(833 \mathrm{~K})$ following cisplatin treatment

\begin{tabular}{lccc}
\cline { 1 - 2 } Cisplatin $(\boldsymbol{\mu})$ & \multicolumn{2}{c}{ Mean cell survival rate (\%) } & \\
\cline { 1 - 2 }$(-$ EGF) & pEGFP-N3 & pEGFP-GFP & P-value from $\boldsymbol{t}$-test \\
\hline 0.1 & 81.25 & 95.5 & 0.006 \\
0.5 & 69.25 & 78 & 0.008 \\
1.0 & 49.25 & 57.25 & 0.002 \\
$(+E G F)$ & & & \\
0.1 & 93.25 & 98 & 0.047 \\
0.5 & 87.75 & 97.5 & 0.001 \\
1.0 & 64.25 & 75.25 & 0.004 \\
\hline
\end{tabular}

Cells expressing EGFR (pEGFR-GFP) were compared with control cells (pEGFP-N3) for cell survival following cisplatin treatment in the presence and absence of EGF $(n=4)$.

with cisplatin, adriamycin, or MMC (Figure 1). Examination of the established cell lines as well as primary germcell tumours for genetic alteration of several key repair factors and damage signalling factors indicated that drug sensitivity of germline
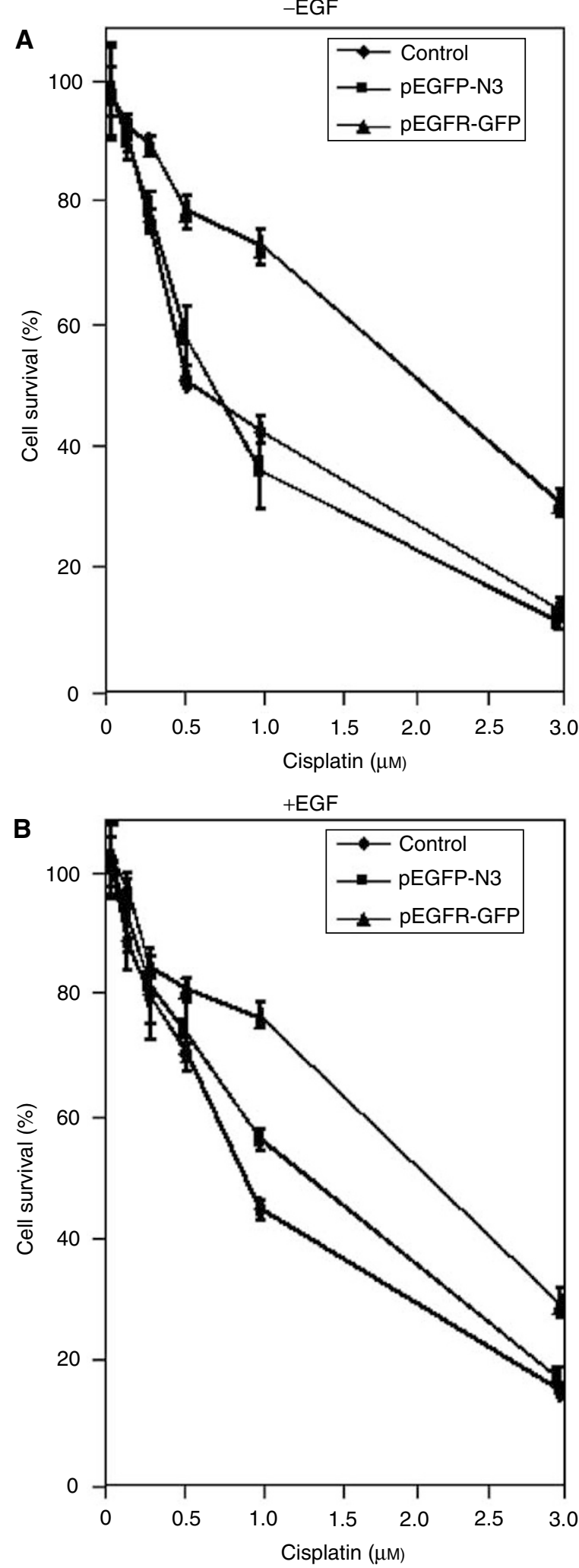

Figure 5 Overexpression of EGFR markedly increased the survival of PA-I cells following cisplatin treatment. Control cells (PA-I) were compared with those stably transfected with either pEGFP-N3 vector or pEGFR-GFP for their cell survival in the presence $(\mathbf{A})$ and absence $(\mathbf{B})$ of EGF following cisplatin treatment. At $24 \mathrm{~h}$ after the seeding, cells were exposed to the indicated amount of cisplatin for 7 days before counting colonies ( $>50$ cells colony ${ }^{-1}$ ). Each point is the mean value of triplicate experiments. 
Table 2 Germ cell tumour (GCT) samples scored for EGFR expression by immunohistochemistry

\begin{tabular}{|c|c|c|c|c|c|}
\hline GCT\# & EGFR & GCT\# & EGFR & GCT\# & EGFR \\
\hline LSAB & ++++ & GCT 1218 & + & GCT । |91 & - \\
\hline GC control & + & GCT । I08-2 & + & GCT I I7| & - \\
\hline GCT I22। & + & GCT ।|3|-2 & - & GCT । I69 & - \\
\hline GCT । I30-2 & + & GCT । I32 & - & GCT । 190 & - \\
\hline GCT $|\|| 5$ & - & GCT । | 42 & + & GCT । 183 & - \\
\hline GCT I230-2 & + & GCT I।I6 & - & GCT । 182 & - \\
\hline GCT 1206 & + & GCT I I 24 & - & GCT । 181 & + \\
\hline GCT 1110 & + & GCT । I 27 & - & GCT । I56 & + \\
\hline GCT 1208 & + & GCT । I I 8 & - & GCT I I22 & + \\
\hline GCT । I06 & - & GCT 1229 & - & GCT । 199 & - \\
\hline GCT । I08 & + & GCT । | 44 & - & GCT । 198 & - \\
\hline GCT । I35 & - & GCT I 202 & + & GCT I I 60 & + \\
\hline GCT । | 43-2 & - & GCT II54 & - & GCT I 204 & - \\
\hline GCT II34 & - & GCT II53 & - & GCT I 224 & + \\
\hline GCT 1215 & - & GCT I|5। & - & GCT । I58 & + \\
\hline GCT । | 82-2 & + & GCT I। 50 & - & & \\
\hline GCT 1212 & + & GCT I। $60-2$ & - & & \\
\hline GCT । | 45-2 & + & GCT I | 47 & + & & \\
\hline GCT । I 25 & + & GCT I|6I-2 & - & & \\
\hline GCT I097-2 & + & GCT 2470-9 & - & & \\
\hline GCT 1098 & + & GCT II 65 & - & & \\
\hline GCT IIO0 & + & GCT । I66 & - & & \\
\hline GCT II38 & - & GCT I I 68 & - & & \\
\hline GCT 1214 & - & GCT । 194 & - & & \\
\hline
\end{tabular}

Two control cells (ovarian cancer cells (Hey, LSAB) and a normal germ cell, GC control) were included to compare the level of EGFR expression in GCT. '-' represents no detectable EGFR expression, while the level of protein expression was determined by comparing with two control cells, GC control at the lowest level $(+)$ and LSAB at the highest level $(++++)$.

tumour cells may not be due to an alteration of repair factors or DNA repair activity (Figure 2). Instead, there was a good correlation between EGFR expression (or EGF-induced JNK activation) and drug resistance among ovarian and germline tumour cells. Low level of EGFR expression in germline tumour cells may be linked to their drug sensitivity and supports a positive role for EGFR in drug resistance of cancer. The latter may be explained by the fact that EGF and its receptor activate the JNK signalling pathway that leads to the induction of genes involved in DNA repair and cellular redox (Adler et al, 1992; Foltz et al, 1998; Roulston et al, 1998).

Epidermal growth factor receptor is a $170 \mathrm{kDa}$ transmembrane glycoprotein with tyrosine kinase activity. Although EGFR was shown to have no independent prognostic significance in advanced cancer (Baekelandt et al, 1999), the EGFR and HER2/neu were frequently overexpressed in malignant tumours. Recent microassay analysis revealed that amplification of EGFR gene was found in many tumours including ovarian cancer (Lei et al, 1999), glioblastoma (Hui et al, 2001), pancreatic cancer (Bruell et al, 2003; Schreiner et al, 2003), gastric cancer (Garcia et al, 2003), prostate cancer (Skacel et al., 2001), and lung adenocarcinoma and head/

\section{REFERENCES}

Adler V, Franklin C, Kraft A (1992) Phorbol ester stimulate the phosphorylation of c-Jun but not v-Jun: regulation by the N-terminal delta domain. Proc Natl Acad Sci USA 89: 5341-5345

Asagoshi K, Yamada T, Terato H, Ohyama Y, Monden Y, Arai T, Nishimura S, Aburatani H, Lindahl T, Ide H (2000) Distinct repair activities of human 7,8-dihydro-8-oxoguanine DNA glycosylase and formamidopyrimidine DNA glycosylase for formamidopyrimidine and 7,8-dihydro-8oxoguanine. J Biol Chem 275: 4956-4964

Arteaga C (2003) Targeting HER1/EGFR: a molecular approach to cancer therapy. Semin Oncol 30: $3-14$ neck squamous cell carcinoma (Haedicke et al, 2003; Shintani et al, 2003), suggesting that overexpression of EGFR may be linked to the oncogenesis of various cancers. High level of EGFR expression also correlates with increased tumour resistance to radiation (Shintani et al, 2003), suggesting that EGFR may mediate radioresistance of cancer cells (Liang et al, 2003). Epidermal growth factor receptor is also a cellular receptor for human cytomegalovirus, a cancer-causing virus that causes severe and fatal disease in immune-comprimised individuals (Wang et al, 2003).

Epidermal growth factor receptor-associated protein tyrosine kinase complexes also have vital antiapoptotic functions in human breast cancers (Modjtahedi et al, 1998; Witters et al, 1999) and the blockade of EGFR not only adversely affected cell growth, but also showed a sign of terminal differentiation and induces apoptosis in the human cancer cells (Modjtahedi et al, 1998). Similarly, druginduced apoptosis in human breast cancer cells was abrogated by using EGFR antisense RNA (Dixit et al, 1997), suggesting that a critical level of EGFR signalling, which is amplified in some common cancers, may be necessary for DNA-damaging drugmediated apoptosis in tumour cells and suggest an inhibitory effect of this pathway on the repair of cisplatin-damaged DNA. In fact, cancer cells expressing higher levels of EGFR were much more resistant to the growth inhibitory effect of DNA-damaging agents than were control cells (Dixit et al, 1997).

Various strategies have been developed to target EGFR and to deter cancer cell growth (Zhang et al, 2000; Bruell et al, 2003; Heimberger et al, 2003). For example, the treatment of cancer cells with EGFR tyrosine kinase inhibitor markedly potentiates the efficacy of many cytotoxic agents against several human cancer xenografts (She et al, 2003). The use of antisense oligonucleotides or monoclonal antibodies to EGFR also showed significant inhibition of cancer cell growth (Modjtahedi et al, 1998; Witters et al, 1999), while activation of EGFR family members suppresses the cytotoxic effects of TNF-alpha (Hoffmann et al, 1998).

Although mutations in proto-oncogenes (c-ret) as well as DNA MMR genes have been linked to germline tumours (van Puijenbroek et al, 1997; Leung et al, 2000), alteration of EGFR in germcell tumours has not been reported. This study showed that germline tumour cells not only exhibited lower EGFR expression but also were highly sensitive to DNA-damaging drugs, suggesting that the lack of EGFR expression contributes at least in part to the drug sensitivity of germline cells.

\section{ACKNOWLEDGEMENTS}

We thank Dr A Sorkin for providing us with pEGFP-N3 vector and pEGFP-EGFR, Dr R Bigsby for PA-1 cells, Dr G Mills for Hey and its derivative cells, and Dr J Hurteau for IOSE80 ovarian cell lines. This research was supported by grants from the US Army (DAMD17-00-1-0295) and the National Institute of Health (CA92111). S-J Park was supported by the NIH National Research Service Award (T32 DK07519).
Baekelandt M, Kristensen GB, Trope CG, Nesland JM, Holm R (1999) Epidermal growth factor receptor expression has no independent prognostic significance in advanced ovarian cancer. Anticancer Res 19: $4469-4474$

Bielas JH, Heddle JA (2000) Proliferation is necessary for both repair and mutation in transgenic mouse cells. Proc Natl Acad Sci USA 97: $11391-11396$

Bruell D, Stocker M, Huhn M, Redding N, Kupper M, Schumacher P, Paetz A, Bruns CJ, Haisma HJ, Fischer R, Finnern R, Barth S (2003) The recombinant anti-EGF receptor immunotoxin 425(scFv)-ETA' 
suppresses growth of a highly metastatic pancreatic carcinoma cell line. Int J Oncol 23: 1179-1186

Cagnoli M, Alama A, Barbieri F, Novelli F, Bruzzo C, Sparatore F (1998) Synthesis and biological activity of gold and tin compounds in ovarian cancer cells. Anticancer Drugs 9(7): 603-610

Chetsanga CJ, Lindahl T (1979) Release of 7-methylguanine residues whose imidazole rings have been opened from damaged DNA by a DNA glycosylase from Escherichia coli. Nucleic Acids Res 6: 3673-3684

Cohen NA, Egorin MJ, Snyder SW, Ashar B, Wietharn BE, Pan SS, Ross DD, Hilton J (1991) Interaction of $N, N^{\prime}, N^{\prime \prime}$-triethylenethiophosphoramide and $N, N^{\prime}, N^{\prime \prime}$-triethylenephosphoramide with cellular DNA. Cancer Res 51: $4360-4366$

Demple B, Harrison L (1994) Repair of oxidative damage to DNA: enzymology and biology. Annu Rev Biochem 63: 915-948

Deutsch WA, Yacoub A, Jaruga P, Zastawny TH, Dizdaroglu M (1997) Characterization and mechanism of action of Drosophila ribosomal protein S3 DNA glycosylase activity for the removal of oxidatively damaged DNA bases. J Biol Chem 272: 32857-32860

Dinapoli RP, Brown LD, Arusell RM, Earle JD, O'Fallon JR, Buckner JC (1993) Phase III comparative evaluation of PCNU and carmustine combined with radiation therapy for high-grade glioma. J Clin Oncol 11: $1316-1321$

Dixit M, Yang JL, Poirier MC, Price JO, Andrews PA, Arteaga CL (1997) Abrogation of cisplatin-induced programmed cell death in human breast cancer cells by epidermal growth factor antisense RNA. J Natl Cancer Inst 89: $365-373$

Dobson AW, Xu Y, Kelley MR, LeDoux SP, Wilson GL (2000) Enhanced mtDNA repair and cellular survival following oxidative stress by targeting the hOGG repair enzyme to mitochondria. J Biol Chem 275: $37518-37523$

Doetsch PW, Cunningham RP (1990) The enzymology of apurinic/ apyrimidinic endonucleases. Mutat Res 236: 173-201

Drummond JT, Anthoney A, Brown R, Modrich P (1996) Cisplatin and adriamycin resistance are associated with $\operatorname{MutL} \alpha$ and mismatch repair deficiency in an ovarian tumor cell line. J Biol Chem 271: 19645-19648

Duyster J, Baskaran R, Wang JY (1995) Src homology 2 domain as a specificity determinant in the c-Abl-mediated tyrosine phosphorylation of the RNA polymerase II carboxyl-terminal repeated domain. Proc Natl Acad Sci USA 92: 1555-1559

Eastman A, Schulte N (1998) Enhanced DNA repair as a mechanism of resistance to cis-diammine-dichloroplatinum (II). Biochemistry 27: $4730-4734$

Evans AR, Limp-Foster M, Kelley MR (2000) Going APE over ref-1. Mutat Res 461: 83-108

Ferrera CG, Tols C, Gaccone G (1999) p53 and chemosensitivity. Ann Oncol 10: $1011-1021$

Fink D, Nebel S, Aebi S, Zheng H, Cenni B, Nehme A (1996) The role of DNA mismatch repair in platinum drug resistance. Cancer Res 56: 4881 4886

Fink D, Aebi S, Howell SB (1998) The role of DNA mismatch repair in drug resistance. Clin Cancer Res 4: 1-6

Fishel R, Kolodner RD (1995) Identification of mismatch repair genes and their role in the development of cancer. Curr Opin Genet Dev 5: 382 -395

Foltz IN, Gerl RE, Wieler JS, Luckach M, Salmon RA, Schrader JW (1998) Human mitogen-activated protein kinase kinase 7 (MKK7) is a highly conserved c-Jun N-terminal kinase/stress-activated protein kinase (JNK/ SAPK) activated by environmental stresses and physiological stimuli. J Biol Chem 274: $9344-9351$

Garcia I, del Casar JM, Corte MD, Allende MT, Garcia-Muniz JL, Vizoso F (2003) Epidermal growth factor receptor and c-erbB-2 contents in unresectable (UICC R1 or R2) gastric cancer. Int J Biol Markers 18: $200-206$

Gill RD, Cussac C, Souhami RL, Laval F (1996) Increased resistance to $N, N^{\prime}, N^{\prime \prime}$-triethylenethiophosphoramide (thiotepa) in cells expressing the Escherichia coli formamidopyrimidine-DNA glycosylase. Cancer Res 56: $3721-3724$

Graves RJ, Felzenszwalb I, Laval J, O'Connor TR (1992) Excision of 5'terminal deoxyribose phosphate from damaged DNA is catalyzed by the Fpg protein of Escherichia coli. J Biol Chem 267: 14429-14435

Haedicke W, Popper HH, Buck CR, Zatloukal K (2003) Automated evaluation and normalization of immunohistochemistry on tissue microarrays with a DNA microarray scanner. Biotechniques 35(1): $164-168$

Hansen WK, Deutsch WA, Yacoub A, Xu Y, Williams DA, Kelley MR (1998) Creation of a fully functional human chimeric DNA repair protein.
Combining O6-methylguanine DNA methyltransferase (MGMT) and AP endonuclease (APE/redox effector factor 1; Ref1) DNA repair proteins. J Biol Chem 273: 756-762

Hansen WK, Kelley MR (2000) Review of mammalian DNA repair and translational implications. J Pharmacol Exp Ther 295: 1-9

Heimberger AB, Crotty LE, Archer GE, Hess KR, Wikstrand CJ, Friedman AH, Friedman HS, Bigner DD, Sampson JH (2003) Epidermal growth factor receptor VIII peptide vaccination is efficacious against established intracerebral tumors. Clin Cancer Res 9(11): 4247-4254

Hoffmann M, Schmidt M, Wels W (1998) Activation of EGF receptor family members suppresses the cytotoxic effects of tumor necrosis factor-alpha. Cancer Immunol Immunother 47: 167-175

Hui AB, Lo KW, Yin XL, Poon WS, Ng HK (2001) Detection of multiple gene amplifications in glioblastoma multiforme using array-based comparative genomic hybridization. Lab Invest 81: 717-723

Johnson SW, Perez RP, Godwin AK, Yeung AT, Handel LM, Ozols RF, Hamilton TC (1994) Role of platinum-DNA adduct formation and removal in cisplatin resistance in human ovarian cancer cell lines. Biochem Pharmacol 47: 689-697

Karahalil B, Girard PM, Boiteux S, Dizdaroglu M (1998) Substrate specificity of the Ogg1 protein of Saccharomyces cerevisiae: excision of guanine lesions produced in DNA by ionizing radiation- or hydrogen peroxide/metal ion-generated free radicals. Nucleic Acids Res 26: 1228 1233

Koi M, Umar A, Chauhan DP, Cherian SP, Carethers JM, Kunkel TA, Boland CR (1994) Human chromosome 3 corrects mismatch repair deficiency and microsatellite instability and reduces $N$-methyl- $N^{\prime}$-nitro$\mathrm{N}$-nitrosoguanidine tolerance in colon tumor cells with homozygous hMLH1 mutation. Cancer Res 54: 4308-4312

Kuga T, Sakamaki S, Matsunaga T, Hirayama Y, Kuroda H, Takahashi Y, Kusakabe T, Kato I, Niitsu Y (1997) Fibronectin fragment-facilitated retroviral transfer of the glutathione-S-transferase pi gene into CD34+ cells to protect them against alkylating agents. Hum Gene Ther 8: 1901 1910

Laemmli UK (1970) Cleavage of structural proteins during assembly of the head of bacteriophage T4. Nature 227: 680-685

Lai GM, Ozols RF, Smyth JF, Young RF, Hamilton TC (1988) Enhanced DNA repair and resistance to cisplatin in human ovarian cancer. Biochem Pharmacol 37: 4597-4600

Lei W, Mayotte JE, Levitt ML (1999) Enhancement of chemosensitivity and programmed cell death by tyrosine kinase inhibitors correlates with EGFR expression in non-small cell lung cancer cells. Anticancer Res 19: $221-228$

Leighton C, Fisher B, Bauman G, Depiero S, Stitt L, Macdonald D, Cairncross G (1997) Supratentorial low-grade gliomas in adults: an analysis of prognostic factors and timing of radiation. J Clin Oncol 15: $1294-1301$

Leung SY, Yuen ST, Chan TL, Chan AS, Ho JW, Kwan K, Fan YW, Hung KN, Chung LP, Wyllie AH (2000) Chromosomal instability and p53 inactivation are required for genesis of glioblastoma but not for colorectal cancer in patients with germline mismatch repair gene mutation. Oncogene 19: 4079-4083

Liang K, Ang KK, Milas L, Hunter N, Fan Z (2003) The epidermal growth factor receptor mediates radioresistance. Int J Radiat Oncol Biol Phys 57(1): $246-254$

Limp-Foster M, Kelley MR (2000) DNA repair and gene therapy: implications for translational uses. Environ Mol Mutagen 35: 71-81

Litz-Jackson S, Miller AH, Burgess GS, Boswell HS (1992) Dissociation of nuclear events on p21 RAS transformation of FDC-P1 myeloid cells c-jun/AP1 expression versus c-myc transcription. Blood 79: 2404-2414

Lydon NB, Mett H, Mueller M, Becker M, Cozens RM, Stover D, Daniels D, Traxler P, Buchdunger E (1998) A potent protein-tyrosine kinase inhibitor which selectively blocks proliferation of epidermal growth factor receptor-expressing tumor cells in vitro and in vivo. Int J Cancer 76: $154-163$

Mello JA, Acharya S, Fishel R, Essigmann JM (1996) The mismatch-repair protein hMSH2 binds selectively to DNA adducts of the anticancer drug cisplatin. Chem Biol 3: 579-589

Mitra S, Hazra TK, Roy R, Ikeda S, Biswas T, Lock J, Boldogh I, Izumi T (1997) Complexities of DNA base excision repair in mammalian cells. Mol Cell 7: 305-312

Modjtahedi H, Affleck K, Stubberfield C, Dean C (1998) EGFR blockade by tyrosine kinase inhibitor or monoclonal antibody inhibits growth, directs terminal differentiation and induces apoptosis in the human squamous cell carcinoma HN5. Int J Oncol 13: 335-342 
Mohrenweiser HW, Wilson III DM, Jones IM (2003) Challenges and complexities in estimating both the functional impact and the disease risk associated with the extensive genetic variation in human DNA repair genes. Mutat Res 526: $93-125$

O’Neill JP (2000) DNA damage, DNA repair, cell proliferation, and DNA replication: how do gene mutations result? Proc Natl Acad Sci USA 97: $11137-11139$

Park S-J, Oh E-J, Yoo M-A, Lee S-H (2001) Involvement of DNA-dependent protein kinase in regulation of stress-induced JNK activation. DNA Cell Biol 20: $637-645$

Perez M, Donato NJ (1996) Activation of epidermal growth factor receptor tyrosine phosphorylation by tumor necrosis factor correlates with loss of cytotoxic activity. J Interferon Cytokine Res 16: 307-314

Robertson KA, Bullock HA, Xu Y, Tritt R, Zimmerman E, Ulbright TM, Foster RS, Einhorn LH, Kelley MR (2001) Altered expression of Ape1/ref1 in germ cell tumors and overexpression in NT2 cells confers resistance to bleomycin and radiation. Cancer Res 61: 2220-2225

Rosenquist TA, Zharkov DO, Grollman AP (1997) Cloning and characterization of a mammalian 8-oxoguanine DNA glycosylase. Proc Natl Acad Sci USA 94: $7429-7434$

Roulston A, Reinhard C, Amiri P, Williams LT (1998) Early activation of cJun $N$-terminal kinase and p38 kinase regulates cell survival in response to tumor necrosis factor alpha. J Biol Chem 273: 10232-10239

Schreiner B, Greten FR, Baur DM, Fingerle AA, Zechner U, Bohm C, Schmid M, Hameister H, Schmid RM (2003) Murine pancreatic tumor cell line TD2 bears the characteristic pattern of genetic changes with two independently amplified gene loci. Oncogene 22: 6802-6809

She Y, Lee F, Chen J, Haimovitz-Friedman A, Miller VA, Rusch VR, Kris MG, Sirotnak FM (2003) The epidermal growth factor receptor tyrosine kinase inhibitor ZD1839 selectively potentiates radiation response of human tumors in nude mice, with a marked improvement in therapeutic index. Clin Cancer Res 9: 3773-3778

Shintani S, Kiyota A, Mihara M, Sumida T, Kayahara H, Nakashiro KI, Hamakawa H (2003) Enhancement of radiosensitivity in head and neck cancer cells by ZD1839 ('IRESSA'), a selective epidermal growth factor receptor tyrosine kinase inhibitor. Am J Clin Oncol 26(5): E150 - E156

Skacel M, Ormsby AH, Pettay JD, Tsiftsakis EK, Liou LS, Klein EA, Levin HS, Zippe CD, Tubbs RR (2001) Aneusomy of chromosomes 7, 8, and 17 and amplification of HER-2/neu and epidermal growth factor receptor in Gleason score 7 prostate carcinoma: a differential fluorescent in situ hybridization study of Gleason pattern 3 and 4 using tissue microarray. Hum Pathol 32: 1392 - 1397

Stigger E., Drissi R., Lee S-H (1998) Functional analysis of human replication protein A in nucleotide excision repair. J Biol Chem 273: $9337-9343$

Umar A, Koi M, Risinger JI, Glaab WE, Tindall KR, Kolodner RD, Boland CR, Barrett JC, Kunkel TA (1997) Correction of hypermutability, $N$ methyl- $N^{\prime}$-nitro- $N$-nitrosoguanidine resistance, and defective DNA mismatch repair by introducing chromosome 2 into human tumor cells with mutations in MSH2 and MSH6. Cancer Res 57: 3949-3955

van Puijenbroek AA, van Weering DH, van den Brink CE, Bos JL, van der Saag PT, de Laat SW, den Hertog J (1997) Cell scattering of SK-N-MC neuroepithelioma cells in response to Ret and FGF receptor tyrosine kinase activation is correlated with sustained ERK2 activation. Oncogene 14: $1147-1157$

Wang X, Huong SM, Chiu ML, Raab-Traub N, Huang ES (2003) Epidermal growth factor receptor is a cellular receptor for human cytomegalovirus. Nature 424(6947): 456-461

Waters TR, Gallinari P, Jiricny J, Swann PF (1999) Human thymine DNA glycosylase binds to apurinic sites in DNA but is displaced by human apurinic endonuclease 1. J Biol Chem 274: 67-74

Witters L, Kumar R, Mandal M, Bennett CF, Miraglia L, Lipton A (1999) Antisense oligonucleotides to the epidermal growth factor receptor. Breast Cancer Res Treat 53: $41-50$

Zhang HT, Wang Q, Greene MI, Murali R (2000) New perspectives on antiHER2/neu therapeutics. Drug News Perspect 13(6): 325-329

Zharkov DO, Rosenquist TA, Gerchman SE, Grollman AP (2000) Substrate specificity and reaction mechanism of murine 8-oxoguanine-DNA glycosylase. J Biol Chem 275: $28607-28617$ 